Research Article

\title{
Evaluation of burn wound healing property of ocimum sanctum by monitoring of period of re-epithelization in rabbits
}

\author{
Vaibhav K. Gupta ${ }^{*}$, Swanand S. Pathak ${ }^{2}$, Mahesh K. Jain ${ }^{2}$
}

${ }^{1}$ Department of Pharmacology, C.C.M. Medical College, Durg (C.G.), India,

${ }^{2}$ Department of Pharmacology, J.N. Medical College, Sawangi (M), Wardha, Maharashtra, India

Received: 7 November 2015 Accepted: 19 December 2015

\author{
*Correspondence to: \\ Dr. Vaibhav K. Gupta, \\ Email: \\ vaibhuhotmind007@gmail.com
}

Copyright: () the author(s), publisher and licensee Medip Academy. This is an open-access article distributed under the terms of the Creative Commons Attribution Non-Commercial License, which permits unrestricted non-commercial use, distribution, and reproduction in any medium, provided the original work is properly cited.

\begin{abstract}
Background: Burns remain a major public health problem all over the world, especially in developing countries. Pseudomonas aeruginosa is a major cause of infection and a contributing factor in the death of patients with burns. So, there is a growing need to develop drugs which will prevent infections and complications more effectively than the presently used drugs. Ocimum sanctum $L$. (Tulsi in Hindi) has been shown to have antioxidant properties, which may be responsible and favorable for faster wound healing. The present study was carried out to evaluate the wound healing property of $O$. sanctum by monitoring the period of re-epithelization in thermal burns with and without supportive treatment of ointment silver sulfadiazine.

Methods: Wound healing property of $O$. sanctum was evaluated by monitoring the period of re-epithelization.

Results: The period of re-epithelization, in Control group was $34 \pm 1.26$ days, in Standard group treated with ointment silver sulfadiazine was $30.33 \pm 1.37$ days, in group treated with $O$. sanctum was $30.50 \pm 1.87$ days and in group treated with ointment silver sulfadiazine $+O$. sanctum was $26 \pm 1.41$ days.

Conclusions: Group treated with ointment silver sulfadiazine $+O$. sanctum showed minimum re-epithelization period. So, the most effective treatment for burn wound healing in this study was ointment silver sulfadiazine $+O$. sanctum.
\end{abstract}

Keywords: Burn, Ocimum sanctum, Silver sulfadiazine, Re-epithelization period

\section{INTRODUCTION}

Ayurveda remains one of the most ancient and yet alive tradition practiced widely in India, Sri Lanka and other countries that have a sound philosophical and experiential basis. $^{1}$

Burn can be defined as tissue damage caused by a variety of agents such as heat, chemicals, electricity, sunlight or nuclear radiation. The most common are burns caused by scalds, building fires and flammable liquids and gases. Every year, about two million people receive medical treatment for burn injury. ${ }^{2}$

Wounds are injuries that results in an opening and break of the skin that causes disturbance in the normal skin anatomy and function. The process of wound healing consists of integrated cellular or biochemical events leading to the building of structural and functional integrity of injured tissues. Plant products are potential agents for wound healing, and largely preferred because of their widespread availability and effectiveness as crude preparations. ${ }^{3}$

The gold standard in topical burn treatment is silver sulfadiazine a useful antibacterial agent for burn wound treatment. $^{4}$

Ocimum sanctum L. (Holy basil in English and Tulsi in Hindi) has been shown to have antioxidant properties, which may be responsible and favourable for faster wound healing. ${ }^{5}$

Pseudomonas aeruginosa is a major cause of infection and death or a contributing factor in the death of patients with severe burns. ${ }^{6}$

So, there is a growing need to develop drugs which will decrease the complications and prevent infections more effectively than the presently used drugs. The present 
study was carried out to evaluate the wound healing property of $O$. sanctum by monitoring period of reepithelization with and without supportive treatment of standard drug ointment silver sulfadiazine in rabbits.

\section{METHODS}

This is a preclinical experimental study on rabbits. The Study protocol was approved by Institutional Animal Ethics Committee.

\section{Procurement of plants material}

The Plant material of $O$. sanctum (Leaves Powder) was obtained from Mahatma Gandhi Ayurved College, Salod, Wardha, Maharashtra, India.

\section{Procurement of ointment silver sulfadiazine}

Ointment Silver sulfadiazine was procured from Rexcin Pharmaceuticals Private Limited, Solan, Himachal Pradesh, India.

\section{Procurement of anaesthetic agent}

Injection Aneket (Ketamine Hydrochloride Injection I.P.) was procured from Neon Laboratories Limited, Thane, Maharashtra State, India.

\section{Animals}

24 Rabbits were obtained from Central Animal House of University. Rabbits of both sex (either male or female), age group of 6-8 months and weight $1.5 \mathrm{~kg}-2 \mathrm{~kg}$ were included. Unhealthy and pregnant rabbits were excluded.

\section{Grouping of animals}

24 rabbits with age group of 6-8 month and weight 1.5 to $2 \mathrm{~kg}$ were divided randomly into 04 groups of 06 animals each (Table 1).

\section{Preparation of animals}

Animals were acclimatized for 8 days before experiment. Animals were housed in separate cages under standard condition of light, temperature and humidity. They were fed with standard laboratory chow and provided with water ad libitum.

\section{Infliction of burn wound}

The area on the back of the rabbit was to be shaved and animal kept for fasting overnight. The next day the animals were anaesthetized using Ketamine in the dose of $50 \mathrm{mg} / \mathrm{Kg}$ of body weight I.M. (1 ml/kg of body weight). A metal disc of diameter $22 \mathrm{~cm}$, thickness $5 \mathrm{~mm}$ and area $380.2 \mathrm{~mm}^{2}$ was heated in the blue portion of the flame for
5 minute and then immediately kept on the shaved part for 30 seconds with minimal pressure. ${ }^{7}$

\section{Administration and application of drugs}

Ointment silver sulfadiazine was applied daily on the burn wound. $O$. sanctum was administered orally in the form of distilled water suspension in the dose of 500 $\mathrm{mg} / \mathrm{kg}$ body weight once daily.

\section{Estimation of healing by monitoring period of re- epithelization}

Falling of eschar leaving no raw wound area was considered as end point of complete epithelization and the days required for this was taken as period of reepithelization. ${ }^{8}$

\section{Statistical analysis}

Results were reported as mean \pm standard deviation.

\section{RESULTS}

The period of re-epithelization, in control group was $34 \pm$ 1.26 days, in standard group treated with ointment silver sulfadiazine was $30.33 \pm 1.37$ days, in group treated with $O$. sanctum was $30.50 \pm 1.87$ days and in group treated with ointment silver sulfadiazine $+O$. sanctum was $26 \pm$ 1.41 days (Table 2).

Table 1: Grouping of animals.

\begin{tabular}{|llc|}
\hline $\begin{array}{l}\text { Sr. } \\
\text { No. }\end{array}$ & Group & Animals \\
\hline 1. & $\begin{array}{l}\text { Control group : not receiving any } \\
\text { treatment }\end{array}$ & 06 \\
\hline 2. & $\begin{array}{l}\text { Standard group: treated with silver } \\
\text { sulfadiazine }\end{array}$ & 06 \\
\hline 3. & Test group 1: treated with O. sanctum & 06 \\
\hline 4. & $\begin{array}{l}\text { Test group 2: treated with silver } \\
\text { sulfadiazine }+ \text { O. sanctum }\end{array}$ & 06 \\
\hline & & \\
\hline
\end{tabular}

Table 2: Period of re-epithelization.

\begin{tabular}{|ll|}
\hline Group & $\begin{array}{l}\text { Period of Reepithelization } \\
(\text { Mean } \pm \text { S.D. }\end{array}$ \\
\hline Control & $34 \pm 1.26$ \\
\hline Standard & $30.33 \pm 1.37$ \\
\hline Os & $30.50 \pm 1.87$ \\
\hline SS+Os & $26 \pm 1.41$ \\
\hline
\end{tabular}

\section{DISCUSSION}

The most effective group was ointment silver sulfadiazine $+O$. sanctum and probable reason of high effectiveness was the combined effect of ointment silver sulfadiazine and $O$. sanctum, broad spectrum 
antimicrobial activity of silver sulfadiazine and antioxidant and wound healing property of $O$. sanctum.

Study conducted by Hossenimehr SJ et $\mathrm{al}^{9}$ on Effect of Aloe cream versus silver sulfadiazine for healing burn wounds in rats, reported that the antimicrobial effect is the major mechanism of silver sulfadiazine in wound healing. The silver ion binds to the organism DNA and consequently releases the sulfonamides that kill the microbes.

Another study conducted by Hoekstra MJ et $\mathrm{al}^{10}$ on effect of silver sulfadiazine on histopathological parameters of burn wound in pig was reported that silver sulfadiazine causes rapid healing through stimulating of reepithelization, formation of granulation tissue and increase in fibroblasts.

Study conducted by Asha B et $\mathrm{al}^{11}$ on study of wound healing activity of topical $O$. sanctum Linn in albino rats reported that the topical $O$. sanctum treated wound, which showed greater degree of neovascularization and fibroblast proliferation indicates better granulation tissue formation and collagenization on day. ${ }^{4}$ Topical $O$. sanctum showed maximum collagenization and minimum with control. Epithelization was early and complete with topical $O$. sanctum on day. ${ }^{7}$

\section{CONCLUSION}

Group treated with ointment silver sulfadiazine $+O$. sanctum showed minimum reepithelization period. So, the most effective treatment for burn wound healing in this study was ointment silver sulfadiazine $+O$. sanctum.

\section{ACKNOWLEDGEMENTS}

Authors are very thankful to Management of D.M.I.M.S. (Deemed University) for providing all facilities required to complete this work.

Funding: No funding sources Conflict of interest: None declared

Ethical approval: Study protocol was approved by Institutional Animal Ethics Committee.

\section{REFERENCES}

1. Patwardhan B, Vaidya ADB, Chorghade $\mathrm{M}$. Ayurveda and herbal products drug discovery. Curr Sci. 2004;86(6):789-99.
2. Shrivastava P, Durgaprasad S. Burn wound healing property of Cocos nucifera: an Appraisal. Indian J Pharmacol 2008;40:144-6.

3. Kumari P, Yadav P, Verma PR, Kumar S, Arya A. A review on wound healing properties of Indian medicinal plants. Ind J Fund Appl Life Sci. 2013;3:220-32.

4. Atiyeh BS, Costagliola M, Hayek SN, Dibo SA. Effect of silver on burn wound infection control and healing: review of the literature. Burns. 2007;33:139-48.

5. Goel A, Kumar S, Singh DK, Bhatia AK. Wound healing potential of $O$. sanctum Linn. with induction of tumor necrosis factor- $\alpha$. Indian $J$ Exp Biol. 2010;48:402-6.

6. Sutter VL, Hurst V. Sources of Pseudomonas aeruginosa infection in burns: study of wound and rectal cultures with phage typing. Ann Surg. 1966;163:597-602.

7. Pathak SS, Borkar MA, Patel SS. A Comparison on healing effect of an ayurvedic preparation and silver sulfadiazine on burn wounds in albino rats. Journal of Datta Meghe Institute of Medical Sciences University. 2006;2:81-7.

8. Udupa SL, Shetty S, Udupa AL, Somayaji SN. Effect of $O$. sanctum Linn. on normal and dexamethasone suppressed wound healing. Indian $\mathbf{J}$ Exp Biol. 2006;44:49-54.

9. Hosseinimehr SJ, Khorasani G, Azadbakht M, Zamani P, Ghasemi M, Ahmadi A. Effect of aloe cream versus silver sulfadiazine for healing burn wounds in rats. Acta Dermatovenerol Croat. 2010;18:2-7.

10. Hoekstra MJ, Andrews L. Effect of silver sulfadiazine on histopathologic parameters of burn wound in pig. Burns. 1993;29:544-7.

11. Asha B, Nagabhushan A, Shashikala GH. Study of wound healing activity of topical $O$. sanctum Linn in Albino Rats. J Chem Pharm Res. 2011;3:122-6.

Cite this article as: Gupta VK, Pathak SS, Jain MK. Evaluation of burn wound healing property of ocimum sanctum by monitoring of period of reepithelization in rabbits. Int J Basic Clin Pharmacol 2016;5:146-8. 